\title{
Reforming Taxes and Customs
}

\begin{abstract}
This chapter describes how Georgia's government ended the rule of the shadow economy with the help of tax and customs reforms. The key was simplicity. The number of general taxes was cut from 21 to 6 , all of them low, flat, and simple, and despite this action tax collections increased tenfold in the period of nine years (2003-2011) in nominal terms and from 7 to 24 percent in terms of percent to GDP. The number of customs duties was reduced from 16 to 3 . More than 90 percent of all imported goods were allowed into the country without any customs duty, making Georgia one of the most open economies in the region. The author also outlines some innovative approaches to tax administration such as outsourcing of tax audits to private sector, using lottery for improved tax compliance, etc. The chapter concludes with a discussion of the Estonian model of profit taxation.
\end{abstract}

Keywords Roadshow · E-filing · Mediation · Ombudsman · Prime Minister

In 2004, Georgia's government set out to end the rule of the shadow economy that had brought the country to the brink of bankruptcy. Specifically, the government vowed to create a transparent system of rules that would spur on both domestic entrepreneurship and foreign investment. The key was simplicity. The number of general taxes was cut 
from 21 to 7 . The number of customs duties was reduced from 16 to 3 . More than 90 percent of all imported goods were allowed into the country without any customs duty, making Georgia one of the most open economies in the region. New technology was introduced to improve tax and customs administrations; examples include compulsory e-filing of tax returns and proprietary software to spot irregularities and trigger tax audits. To ease the bureaucratic burden for small businesses, simplified tax keys were introduced, e.g., based on the number of chairs at a barbershop or the number of tables at a restaurant.

\subsection{Tax Code Simplification}

Reducing both the number of taxes and the tax rate led to a significant boost in tax revenues; see Chap. 3, Rightsizing Fiscal and Monetary Policies. These policies were the most visible elements of our tax reform, but they constituted only a small part of a much larger package of legal and administrative improvements. Our mission was to introduce any change that would help reduce corruption. Cleaning up the tax department itselflaying off people, recruiting new specialists - was an important step, but it was not enough. Like most developing countries, Georgia suffered from a lack of high-caliber tax professionals, and most of the really good ones were employed by the private sector, where wages were much higher than in the tax department. As a result, the talent pool for tax auditors was frightfully small. We were afraid that auditors would jump at any chance to take advantage of ambiguity and bend the rules in favor of those who were willing to pay for it. To prevent this from happening, we made the rules as simple and transparent as possible, leaving no room for interpretation. This made the system largely immune to abuse, and it enabled even a small team of auditors to enforce it. It worked. In a survey conducted by Transparency International ("Global Corruption Barometer") in 2012, 0 percent of respondents said that they had paid a bribe to the tax department (Fig. 5.1). ${ }^{1}$

In 2004, Georgia introduced its new tax code, decreasing the number of taxes from 21 to 7 (and to 6 a year later). All taxes were flat and low. There was no incentive to make one's income appear lower than it really was to get into a lower tax bracket. The income tax rate was 25 percent for everybody. In 2009, it was decreased to 20 percent. The profit tax rate was 15 percent, the dividend tax rate 5 percent, the VAT rate was 18 percent, and the property tax rate was up to 1 percent, depending on the local authorities. 


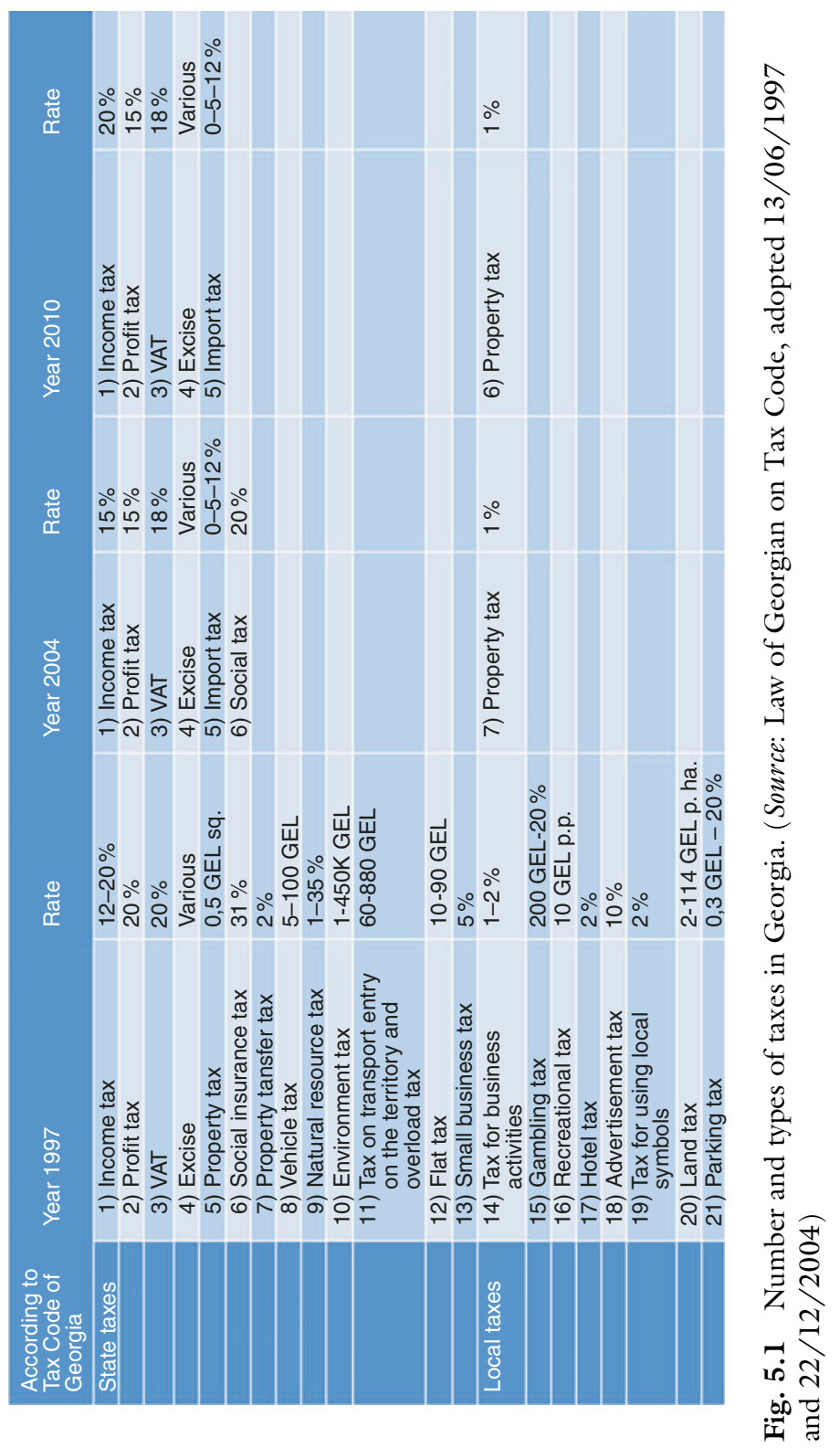


The social tax was abolished as part of the one budget principle that gives the government freedom to use tax revenue as needed, i.e., without earmarking, regardless of its source. In 2011, the government introduced a special tax for SMEs, merging all duties into one to reduce the administrative burden. SMEs could not afford accountants, which is why even the simplified new tax code was still too difficult for them. To make their lives as easy as possible, the merged revenue tax was calculated based on variables that reflected the respective type of business. Examples include:

- Number of beds for small bed and breakfast establishments

- Number of chairs for barber shops

- Number of tables for small restaurants

For small traders and retailers, the merged revenue tax was calculated as a percentage of total revenue. The simplifications helped make tax compliance the new normal. For the first time in Georgia's recent history, everybody contributed.

\subsection{Mediation}

One of the biggest sources of debate and disagreement among the members of the government was the treatment of the private sector by the public prosecutor's office. During the first wave of our reforms (2004-2007), it had been important to take a strong stance on tax issues and make sure that everybody paid fully, especially given the reduced number of taxes and the reduced tax rates. However, the prosecutor's office upheld its pressure on businesses past this period. While this practice did not add much value in terms of tax revenue, it increasingly prompted the hostility of business owners toward the government, sometimes rightfully so. I was part of a group within the government that did its best to reduce the pressure on businesses and ensure they were given fair treatment by the authorities. To this end, we introduced the Internal Dispute Resolution Mechanism (IDRM), a two-round mediation approach. The first round of mediation was conducted by the revenue service itself. If the first round did not bring resolution, the dispute went to the Ministry of Finance. The IDRM panel consisted of the top tax specialists at the Ministry of Finance and of selected members of parliament.

While the IDRM wasn't perfect, it was still the fastest and fairest tool to resolve disputes between the tax department and the private sector. It also 
helped improve the performance of tax auditors. This was because the auditors had to defend their rulings in front of the highly qualified, very well-paid tax specialists that represented private companies in disputes. Additionally, the IDRM helped us put the finger on flaws in the tax code. In disputes between private sector lawyers and tax department auditors, it often turned out that both parties were right - from a legal perspective. The issue was rooted in the regulation itself - it was unclear or ambiguous, and could be interpreted in two or more ways. In some cases, changes to the tax code were introduced as a result of such findings. For the most part, the ruling of the IDRM was designated as a precedent-setting public ruling, i.e., it was to be applied in all similar cases in the future.

Another institution that was created to protect the private sector from potential abuse was the office of the business ombudsman. The ombudsman was tasked with acting as a mediator between the private sector and the government - not only regarding tax disputes, but other issues as well, such as licensing, permits, privatization, and registration of businesses. The job of the ombudsman was to identify any such contentious issues the private sector - mostly SMEs - might have with specific government agencies, give timely information to the Prime Minister's Office, create an efficient channel of communication, and play the role of a mediator before things got out of hand.

\subsection{IT-Enabled Risk Assessment and Outsourcing of Audits}

Mediation revealed many problems and inefficiencies in the tax department. The biggest problem was the lack of human resources. Although salaries were not low, good tax auditors were hard to find. And although some of the country's best tax specialists worked for the Ministry of Finance, their capacity was insufficient to monitor and enforce tax compliance as broadly as it was deemed necessary. In response, we introduced an IT-based risk assessment to spot tax violations and decided to outsource some of the functions of the tax department.

The risk assessment tool was a software we had developed in-house. It compared financial data filed by companies of similar size operating in the same industry, identified outliers, and detected implausible entries. This scan was based on parameters such as revenue, profit margin, average salaries of employees, changes in revenue and profit, and other indicators. If any of these figures was at odds with those of other enterprises in the same 
industry, the system would detect the anomaly immediately. In effect, we had put in place a pattern recognition solution fueled by big data before either term became popular. We made it a rule of thumb to conduct 80-90 percent of all tax audits based on the IT system. Only 10-20 percent of audits were triggered by the head of the tax department. The objective was to conduct all audits based on the tool and thereby eventually eliminate any opportunity for the tax department, or the financial police, to abuse their power.

The IT-based risk assessment was aided by the introduction of compulsory e-filing, ${ }^{2}$ a measure that, in and of itself, played a major role in decreasing Georgia's shadow economy. Initially, e-filing was introduced for large companies only. The objective was to minimize interaction between taxpayers and the tax department to leave less room for manipulation and corrupt deals. But when e-filing was launched for all companies, only 5 percent chose to use it. Apparently, taxpayers didn't believe that electronic filing was sufficient. What is more, accountants were reluctant to give up their position of power as intermediaries between taxpayers and the tax department. Although the government ran a dedicated communication campaign, the e-filing system was not gaining sufficient traction. Eventually, the government had to disallow any paper-based tax returns. Ever since, all tax returns in Georgia have been filed electronically.

To increase the tax department's coverage of the economy and make the lives of taxpayers easier, the government decided to outsource some functions of the tax department in 2011 - a highly innovative measure at the time. The Ministry of Finance identified ten private tax-auditing companies and gave them a special license to conduct audits of private companies on behalf of the tax department. ${ }^{3}$ If a private company was up for an audit, the company in question would propose one of the ten licensed private auditors to the Ministry of Finance; any auditing firm that had recently provided services to the auditee would not be admitted. The ministry would check if there was any danger of a conflict of interest. If it found that there wasn't, the ministry would authorize the private auditor to represent the revenue service and audit the company on behalf of the tax department. All licensed private auditors were subject to random double checks. If any irregularities were found, the license would be annulled. Once a private enterprise had been notified in writing that an audit by the tax department itself was imminent, this enterprise could no longer choose to be 
audited by a licensed private auditor. This was to encourage companies to apply for private audits before they had even been earmarked for checks by the government. When a private auditor had completed an audit, the auditee could challenge the rulings through IDRM overseen by the Ministry of Finance. In these cases, the private sector's best tax specialists would take up the issue with their peers - one group acting on behalf of the audited company, the other on behalf of the licensed private tax auditor. The final decision was up to the Ministry of Finance. It was a win-win-win approach:

- Private sector companies gladly paid to be audited by licensed private auditors, rather than by public auditors. This was because the tax department's auditors were often perceived as bossy and interfered with business operations during an audit, while private auditors were typically more sympathetic to the needs of auditees to run their businesses.

- Licensed private auditors were happy to have found a new source of income, and they had little reason to put this substantial revenue stream in jeopardy by accepting bribes from auditees in exchange for favorable audits.

- The Ministry of Finance achieved its goal of covering a much bigger part of the economy, and increase tax compliance, despite its limited resources. As a side benefit, the quality of IDRM debates greatly increased because high-caliber experts were now involved on both sides.

\subsection{Additional Measures}

Other measures introduced or envisioned by the government to fight corruption, increase tax compliance, and create a more business-friendly environment included mystery shopping, lotteries on receipts and credit card payments, and electronic tracking and tracing of selected goods, such as cigarettes and alcoholic beverages.

\subsubsection{Mystery Shopping}

To make sure that all shops and commercial entities conducted their business on the record, used registers, and gave out receipts, the tax department employed mystery shoppers. ${ }^{4}$ But since there were only a few of these mystery shoppers, it didn't take long until they were all known to, 
and recognized by, owners of local shops and restaurants. The authorities decided to recruit private mystery shoppers who were trained by the tax department to act on its behalf. These private mystery shoppers did not receive a base salary, but were paid based only on the penalties that they imposed on commercial entities found to be in violation of the tax code. The approach was quite successful for a while, and it helped to reduce the size of the shadow economy. After a few months, however, private mystery shoppers became too aggressive and started taking advantage even of honest business owners. The mystery shopping approach had served its purpose, and the government decided to discontinue it before it could get out of hand.

\subsubsection{Lottery on Receipts}

Shopkeepers and other small commercial entities are always tempted to keep at least a part of their business off the record, i.e., to hide some of their income from the tax department. An easy way to help them resist this temptation is to have shoppers ask for receipts. But how do you get shoppers to do that? By giving them a reward, or at least the prospect of a reward. To take advantage of this disciplinary effect, we introduced a lottery on receipts for cash transactions. Every week, dozens of winners of cash prizes would be drawn, and the results would be widely publicized. The effect was significant. Reported revenue went up every month. After nine months, the increase started to level off, but reported revenue remained high. Originally, the plan was to introduce a similar kind of lottery for credit card payments to cover an even bigger part of the economy and stimulate wider usage of credit cards, which would have helped decrease the size of the cash-based shadow economy. This second stage, however, was never implemented, although preliminary research showed that it would probably have been successful.

\subsubsection{Electronic Tracking and Tracing}

Excised goods, such as cigarettes and alcohol, are naturally elusive. They have a tendency to disappear off the radar of the authorities and change hands as part of the tax-free shadow economy. To counter this tendency and increase legitimate tax revenue, Georgia introduced an Electronic Tracking and Tracing Mechanism (ETTM) for such goods. In cooperation with a foreign private investor, we set up a system that would cover the entire supply chain from manufacturing to retail. 
By the time a given product was made, it had already been assigned a code that was transmitted to the tax department. When the product was put in a box, that box was also marked electronically. The same was true for the van that was used for transportation and its destination, i.e., the particular commercial entity to which the product was delivered for sale. All codes and markings were electronically transmitted to the tax department. Now all a tax inspector had to do was to go to any of the shops and check which products actually belonged there and which ones did not, using an electronic read-out device. The inspector would proceed to investigate the origin, and intended destination, of any product that was found in a store where it didn't belong to pinpoint the perpetrator. To avoid any corrupt deals between inspectors and shopkeepers, the devices inspectors carried were equipped with GPS. That way, the head of tax inspection knew which shop was visited by which employee. The next day, the same store would be visited by a different inspector to double-check the results of the previous day. If any of the shops that had already been inspected was found to stock unregistered goods, the initial inspector was subject to an investigation on charges of corruption and let go if found guilty.

There are many solutions available to track and trace goods in this manner. What set the particular technology we used apart from other solutions was that it assigned and applied electronic markings before a given product was even finished. This made it impossible for the producer to divert part of the production to the black market. This was a key feature. Often, the shipping of goods from factories or warehouses to retailers is the weakest link in the supply chain as far as transparency is concerned. Once the goods enter the retail network, it is very difficult to single out illegitimate batches. When some manufacturers found out about our plans to introduce ETTM, they started to increase their reported revenues by 10 percent almost every month before the system was even in place, assuming that it was better to play by the rules and stop hiding revenue before it was too late and harsh penalties were applied.

\subsection{BAZARS}

In a lot of developing countries, a substantial part of small commerce is conducted in bazars. ${ }^{5}$ Bazars are open-air market places where thousands of traders convene and set up tables or stalls to sell everything from food 
and home appliances to furniture and car parts. Georgia is no exception. The problem is that these transactions are conducted without any registration of traders or taxation of sales. This is why bazars account for a substantial share of the shadow economy. As part of its effort to clean up the economy, the Georgian government attempted to regulate bazars, and collect taxes from traders, as early as 2006. It was a wellintentioned move, but it came too early. Thousands of traders gathered to protest in front of the government building, saying that they shouldn't pay taxes when many other, much wealthier people did not. In many other such cases, the government proceeded with its reforms anyway. But in this case, the protesters were right. A substantial part of Georgia's economy, including many big players, had not come clean at the time, while the protesters were low-income merchants serving poor people. The bazars were the only places where they could conduct their modest business. The reform was suspended - a major blow to tax reform at the time.

In 2011 , the government launched a second attempt to regulate bazars. A special, simplified tax was introduced for small traders. They did not have to pay VAT, calculate their profit, or pay an income tax. All they had to do was pay 4 percent on their total revenue. In conjunction with this move, the government reached out to those who owned the land on which the bazars were held. Since they collected rent from all traders, they were the people who knew the traders' revenues best. Land owners agreed to act as tax agents and collect taxes on behalf of the government. To make the collection process easier and more transparent, the government tried to take cash out of the equation. The proposed concept was modeled on supermarkets. The plan was to give new, big plots of land to landowners, obliging them to develop these plots and build clean, comfortable facilities. A central storage unit was to be constructed, and the plot would have to be accessed through a gated entry and exit point. Customers would not pay merchants in cash, but receive tickets for each transaction and pay for all purchased goods at the exit. That way, it would be much easier to create transparency about each trader's revenues. At the end of each day, traders would present their slips to the central cashier and receive cash for their sales, less the rent and the flat 4 percent tax. Unfortunately, the concept was never fully implemented. Nevertheless, it is a promising approach that could help other countries fight the shadow economy. 


\subsection{The Estonian Model}

In Estonia, undistributed profit is not taxed. In other words, the tax on profits is only collected when profit is paid out to the owner, or owners, of a business as a dividend. If the profit is re-invested in the business, it is not taxed at all. This approach has come to be known as the Estonian model. ${ }^{6}$ It has two major advantages:

1. Investment incentive. Because re-invested profit is not taxed, the model creates additional economic activity, development, and employment.

2. Simplification. Calculating profit tax is the number one source of disputes between private enterprises and the tax department. Since only dividends are taxed, profit does not have to be calculated in the first place. All regulation for tax purposes governing deferment of losses, depreciation, amortization, and transfer pricing between related companies within the country can be abolished. The resulting tax code is very simple and leaves little room for interpretation and corruption.

However, the Estonian model also has two minor drawbacks:

1. Need for new regulation. New rules have to be introduced to clarify which expenses qualify as investments. This is to prevent business owners from evading taxation by using corporate funds for personal expenses, such as cars, houses, or vacations, and labeling these expenses as investments, a maneuver that lets them extract money without paying the dividend tax. While rules to prevent this kind of fraud are much simpler than those governing the calculation of profits, it still requires an extra legislative effort initially.

2. Dip in tax revenue. When introduced, the Estonian model causes a temporary decrease in tax revenue. This is because business owners are usually excited about any new opportunity to save taxes and stop paying out dividends. But this effect quickly wears off. Sooner or later, business owners want to enjoy their profits, resume dividend payments, and start paying taxes again.

In Estonia, the dip in tax revenue leveled off after two years and was fully compensated for by an increase in later years. The Georgian government 
considered introducing the Estonian model but found that proceeds from the tax on profits represented too high a share of total tax revenue (more than 12 percent) at the time, and that there were no financial resources to compensate for the losses during the first few years. At the time of writing, Georgia is making a new effort to introduce the Estonian model, according to press reports: "The government $[\ldots]$ is keen to introduce the Estonian tax model, by which private companies will be exempt from profit tax if they re-invest their profit back into their businesses." 7 The introduction was approved by the parliament on May 13, 2016, and it will take effect in January $2017 .{ }^{8}$ This development should definitely trigger higher economic activity in 2017.

\subsection{Customs Reform}

Much like the tax code, customs regulations were also radically simplified to minimize ambiguity and prevent corruption. But unlike the police department (see chapter on "Fighting Corruption"), the customs department was not reformed overnight. Rather, changes were introduced step by step. Arguing that customs officers need specific knowledge, the administration initially let many old officers keep their jobs and work alongside the new recruits. In reality, the "old guard" realized that the new hires were there to replace them. In an act of self-preservation, they got their new colleagues implicated in their corrupt schemes. This made cleaning up the customs department one of the most difficult, and most time-consuming, part of the fight against corruption in Georgia. The reform wasn't complete until 2011, when most of the old employees had finally been let go and new special customs zones (see later in the chapter) had been created.

The overarching objective of the customs reform was twofold: simplify procedures for the private sector and decrease corruption by ramping up monitoring mechanisms. Key elements of the simplification included:

- The number of customs duties was reduced from 16 to 3 (with rates of 0,5 , and 12 percent). Over 80 percent of all imported goods were cleared at a rate of 0 percent. This made Georgia one of the most open economies in the region. The new customs code is the least protectionist, and most simple, such system in the world.

- All customs services were made part of a one-stop clearance process. Previously, anyone crossing the Georgian border had to go through 
many different check points and get stamps and seals of approval from representatives of as many as half a dozen different government agencies: phytosanitary services overseen by the Ministry of Agriculture (animal and plant disease control), the Department of Cultural Heritage overseen by the Ministry of Culture, the border police overseen by the Ministry of the Interior, the customs department overseen by the revenue service, and so on. The change was as radical as it was simple. In future, all agencies - except for the border police - would be represented by the customs department. If there were any questions regarding the regulation governing particular products, the customs officer was to contact the relevant government agency and clear the goods on its behalf.

- A "golden list" containing the most customs-compliant importers and exporters was compiled. Companies that had a track record of clean books, honest customs declarations, and reliable payments were allowed to take imported goods directly to their warehouses through a special (so called "green") customs corridor. Additionally, they were allowed to pay customs duties with a 30-day delay. These privileges motivated other companies to follow suit, and become more compliant, to be included in the list.

- To support the hub economy concept (see Chap. 4, Creating a Business-Friendly Climate), special customs regulations were introduced, allowing goods to be stored in designated customs-free zones. Customs clearance was due only once the stored goods were sold, an approach that resembles the free port concept that was in effect in Hamburg, Germany, for more than a century. In Georgia, special customs zones were, and still are, widely used by car traders. They import cars to Georgia's special customs zones and only pay customs clearance duties when the cars are sold, often to buyers from other countries in the region. Before long, the designated special customs zones became the places where imported cars are mainly traded. As a result, Georgia has become the biggest car-trading hub in the region, leading to the creation of about 20,000 new jobs.

Additionally, the customs code itself was clarified to eliminate ambiguity; see Chap. 2, Fighting Corruption, for details. These and other simplifications made the clearance process much more business-friendly and greatly improved customs compliance. However, the simplifications were not 
sufficient to eradicate corruption at Georgia's borders completely. This is why additional monitoring measures were introduced:

- Hardware. The government invested in technology to facilitate checks and improve surveillance in customs areas. Scanners and cameras were hot-linked to the surveillance center at the Ministry of Finance. This was to prevent customs officers from manipulating the data feed. Cameras covered all areas of the customs clearance process, from the border crossing itself to the areas in which vehicles and cargo were inspected. The live feed was transmitted directly to the surveillance center, and any misconduct was punished without pardon or exception.

- Software. The ASYCUDA ${ }^{9}$ software system, developed by the United Nations and widely used by customs authorities worldwide, was introduced in Georgia. It is based on four tiers of scrutiny that correspond to color-coded customs gates: green, blue, yellow, and red. Green stands for free passage without any check, while red stands for a detailed check on the spot. Every importer has to pass one of these gates. The color is assigned by an automated risk assessment system. This module is the most important part of the new system; the risk assessment module automatically assigns a given batch of goods to one of the four color-coded gates. Customs officers are not allowed to interfere with the assignment, which is made based on historical data about a given company, a given type of product, and a given country of origin. The automation prevents customs officials from abusing their position of power and granting preferential treatment to importers in exchange for bribes. Ad hoc checks of vehicles or cargo are only permissible under exceptional circumstances and require approval by a supervisor.

The reforms described previously improved the performance of the customs department substantially. The biggest leap came in 2011, when the special customs zones were built. All the previously described policies were in effect in these zones, and the customs department introduced some additional innovations to make the clearance process even more transparent and business friendly:

- All vehicles that crossed the border and carried goods for import were directed to the closest special customs zone. 
- If the clearance process was not completed within 30 minutes, a supervisor would get involved. If the delay was the fault of a customs officer, that officer would be let go. If the delay was due to ambiguous regulations, these regulations would promptly be clarified.

- Brokers were eliminated and all procedures, including the completion of customs forms, were taken over by representatives of the revenue service.

Getting rid of brokers turned out to be the biggest challenge. It is a service that exists in many countries. The broker helps importers deal with the customs department and fill out special customs clearance forms. Filling out these forms was, in fact, a big hurdle for importers in Georgia. They were very complicated and required knowledge of special product codes with which most ordinary business people were unfamiliar. Most brokers were former customs officials with close relations to active members of the customs department. Because of these ties, brokers were able not only to help importers with their forms, but also to charge special fees for preferential treatment. Although it was hard to prove, the general assumption was that brokers passed on a part of the fees they charged to active customs officials. In any case, eliminating these intermediaries made the customs clearance process much more transparent. Employees of the revenue service took the place of brokers and helped importers fill out the required forms. According to independent research, customer satisfaction increased immensely, and Transparency International confirmed that customs-related corruption was reduced. Here is a verbatim statement by an importer: "Three years ago, to import anything, you had to visit ten rooms and pay someone extra money in each room for getting all your papers in order. It created a whole chain of corruption and delay that involved everybody. Today it's much easier. It's very organized there now. There's one room now, and we know in advance how much we'll have to pay." 10

\section{Notes}

1. http://www.transparency.org/research/gcb/overview (retrieved in May 2016).

2. E-filing is defined as "the process of using a computer program to transmit information electronically to another party." (http://www.businessdiction ary.com/definition/e-file.html\#ixzz49eyuFP7x; retrieved in May 2016). 
3. Out of the ten, four were the "Big Four" - international players and six were local companies.

4. In the private sector, a mystery shopper is a person "hired by a market research firm or a manufacturer to visit retail stores, posing as a casual shopper to collect information about the stores' display, prices, and quality of their sales staff." (http://www.businessdictionary.com/definition/mys tery-shopper.html\#ixzz49f3rhd00; retrieved in May 2016).

5. Bazar, sometimes also translated as bazaar, is the Persian word for market.

6. http://www.amcham.ge/diary/rtable_2016-03-09/estonian-model.pdf (retrieved in May 2016).

7. http://mondediplo.com/blogs/georgia-neoliberalism-and-industrial-pol icy (retrieved in May 2016).

8. http://www.messenger.com.ge/issues/3629_may_17_2016/3629_econ_ one.html (retrieved in May 2016).

9. ASYCUDA stands for Automated System for Customs Data (https://www. asycuda.org/; retrieved in May 2016).

10. Stephen F. Jones, The Making of Modern Georgia, Routledge, London/ New York 2014 (p. 108); http://pdf.usaid.gov/pdf_docs/Pdacn591.pdf (retrieved in May 2016) (Jones 2014).

Open Access This chapter is distributed under the terms of the Creative Commons Attribution 4.0 International License (http://creativecommons.org/licenses/by/4.0/), which permits use, duplication, adaptation, distribution and reproduction in any medium or format, as long as you give appropriate credit to the original author(s) and the source, provide a link to the Creative Commons license and indicate if changes were made.

The images or other third party material in this chapter are included in the work's Creative Commons license, unless indicated otherwise in the credit line; if such material is not included in the work's Creative Commons license and the respective action is not permitted by statutory regulation, users will need to obtain permission from the license holder to duplicate, adapt or reproduce the material.

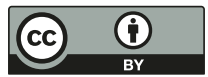

